\title{
Replication report: I. Maternal rations affect the food preferences of weanling rats
}

\author{
M. J. LEVINE \\ Brooklyn College of the City University of New York, Brooklyn, New York 11210 \\ and \\ PAUL M. BRONSTEIN \\ Trenton State College, Trenton, New Jersey 08625
}

\begin{abstract}
Rat pups were reared by foster mothers fed either of two laboratory diets, and pups' intake of these foods was subsequently measured. In confirmation of previous findings, weanlings preferred those rations previously ingested by their maternal caretakers.
\end{abstract}

Galef and Henderson (1972) have shown that rat pups will prefer the food eaten by their mothers during lactation. The present experiment was designed simply to replicate (if possible) the findings of Galef and Henderson.

\section{METHOD}

Our subjects were the offspring of eight Sprague-Dawley albino rats. These females had been obtained from Perfection Breeders of Douglassville, Pennsylvania about 4 days prepartum. Upon arrival in our colony, the animals were switched from the breeders diet (Charles River Original Formula) to Purina Lab Chow and water; these staples were continuously available prior to crossfostering. The rats were housed in polycarbonate delivery cages (Carworth) having a $2-\mathrm{cm}$ bed of Sanicel and newspaper shreds as nesting material. The colony room was illuminated $18 \mathrm{~h} /$ day $(0800$ to 0200$)$ and was heated to $22.2^{\circ} \mathrm{C}$.

Within $24 \mathrm{~h}$ of birth, all litters were culled to six pups. Four days later (Day 4), half of the females were switched to the Turtox diet, with the remainder continuing on the powdered Purina. (These two maternal foods are the same as those used by Galef and Henderson.) Crossfostering also occurred on Day 4. Three pups from each litter were shifted to the care of a dam fed on the diet not eaten by their natural mothers after Day 4 . The other half of each litter remained with their biological mothers during the suckling period. Furthermore, all food was removed from the delivery cages on Day 4 . Mothers were thereafter separated from their young to be fed three 1-h meals daily in wire-mesh cages (Wahmann, Model LC-75/SA). This isolation prevented the young from having any direct contact with the maternal foods prior to testing.

On the 2 days prior to testing, each litter was placed en masse for $1 \mathrm{~h}$ into a cylindrical, clear Plexiglas arena, $24 \mathrm{~cm}$ in diam and $7.2 \mathrm{~cm}$ deep. These enclosures were fitted with two empty foodcups $(5 \times 3 \times 3 \mathrm{~cm})$ that were fastened to the arena walls, $180 \mathrm{deg}$ apart. During the actual testing, these cups were filled with about $5 \mathrm{~g}$ of food tamped down to just below the lower rim of an access hole $(2.25 \mathrm{~cm}$ in diam). Forty-six testing chambers were used (one pup in each of two litters died prior to testing), and all pups were tested individually for a 3-h period on Day 21 . The weanlings were given a choice between Purina and Turtox, with side of food presentation counterbalanced between sub-

This research was supported by Grants MH 22027-01 and MH 26372-01 from the National Institute of Mental Health. M. J. L. was supported by a National Institute of Health Biomedical Predoctoral Fellowship (66 6671).
Table 1 .

Food Consumption Per Subject During a Two-Food Choice Test

\begin{tabular}{lcccc}
\hline & & \multicolumn{2}{c}{ Mean Grams Consumed $\dagger$} & \\
\cline { 3 - 5 } Reared by & $\begin{array}{c}\text { No. of } \\
\text { Sub- } \\
\text { jects* }\end{array}$ & Maternal & $\begin{array}{c}\text { Non- } \\
\text { Maternal }\end{array}$ & $\begin{array}{c}\text { Percent } \\
\text { Purina } \\
\text { Consumed } \dagger\end{array}$ \\
\hline Purina Fed Dams & 14 & $.76 \pm .11$ & $.29 \pm .09$ & $.70 \pm .09$ \\
Turtox Fed Dams & 17 & $.50 \pm .08$ & $.13 \pm .04$ & $.19 \pm .05$ \\
\hline
\end{tabular}

*Due to insufficient eating or excessive spillage, nine Purinareared and seven Turtox-reared pups were eliminated from the results.

tMean \pm SEM.

jects. The weight loss of each food trough was measured on a Mettler balance accurate to $.01 \mathrm{~g}$. Subjects were eliminated from the study due to excessive spillage, or when less than $.01 \mathrm{~g}$ of both foods was eaten. No water was available to the animals during testing.

\section{RESULTS AND DISCUSSION}

The weight of each food eaten was calculated, as was the percentage of Purina taken-i.e., the amount of Purina divided by the total of both diets ingested. Inspection of Table 1 shows that pups reared by Purina-fed dams ate a significantly greater percentage of Purina than the animals reared by Turtox-fed mothers. Furthermore, in each litter there was greater consumption of the maternal than the nonmaternal food $[t(7)=4.24, p<.01]$

The current work indicates clearly that the findings of Galef and Henderson can be replicated. Using the maternal diets previously employed by those authors, pups reared by distinctively fed mothers did prefer the food eaten by their caretaker.

\section{REFERENCES}

Galef, B. G., JR., \& Henderson, P. W. Mother's milk: A determinant of the feeding preferences of weaning rat pups. Journal of Comparative and Physiological Psychology, 1972, 78, 213-219.

(Received for publication May 24, 1976.) 